METALLURGY AND FOUNDRY ENGINEERING - Vol. 38, 2012, No. 1

http://dx.doi.org/10.7494/mafe.2012.38.1.67

Angelika Kmita*, Barbara Hutera**

\title{
THE INFLUENCE OF PHYSICAL AND CHEMICAL PARAMETERS OF MODIFIED WATER GLASS ON THE STRENGTH OF LOOSE SELF-SETTING SANDS WITH WATER GLASS
}

\section{INTRODUCTION}

The period of the last several dozen years has been characterised by an intensive development of loose self-setting sands technology. Loose sands with water glass are characterized by good flowability, small gas volume emission and non-toxicity. Their negative feature is low strength of fresh moulding sand, bad knocking out and weak reclaiming ability. According to the reference data [1] the optimal water glass fraction, with which sand obtains sufficient strength equals $3.5 \%$ (in relation to the matrix).

Investigations presented in papers [1-3] as well as technological practice indicate the problem of total water removal and related to it not complete hardening in the whole mould volume, causing a bad knocking out.

The majority of investigations concerning water glass modification were focused on the organic compounds application [4]. Not numerous results presented in references indicate the favourable influence of micro- and nanoparticles e.g. $\mathrm{MgO}, \mathrm{Al}_{2} \mathrm{O}_{3}, \mathrm{Cr}_{2} \mathrm{O}_{3}$ on the retained strength and due to it, the knocking out improvement [5].

An attempt of water glass modification by $30 \%$ water solution of bochmite $\mathrm{Al}(\mathrm{OH}) \mathrm{O}$ was undertaken in this study. The determination of viscosity and the quartz wettability by modified binders and also the verification of strength properties of loose sands with these binders is the aim of the performed examinations.

* M.Sc., **Ph.D., D.Sc.: AGH University of Science and Technology, Faculty of Foundry Engineering, Krakow, Poland; e-mail: akmita@agh.edu.pl 


\section{THE EXPERIMENTAL PART}

\subsection{Materials and the methodology of examinations}

Water glass R" 145 " of the module $\mathrm{M}=2.5$ and density $d_{20}=1470 \mathrm{~kg} / \mathrm{m}^{3}$, modified with 1, 3, 5 mass \% additions of water solution of bochmite $\mathrm{Al}(\mathrm{OH}) \mathrm{O}$ of a concentration 30 mass $\%$ and an average grain size of app. $10 \mu \mathrm{m}$ - was used in the examinations.

The tested moulding sands had the following components:

- High-silica sand from „Szczakowa“ - 100 parts by mass,

- Water glass R"145" - 3 parts by mass,

- Hardener „Flodur 3 “ $-10 \%$ in relation to the binder,

- Modifier: 30\% water bochmite solution - in amounts: 1, 3 and 5 mass \% .

Water glass modification was carried out by introducing 1,3 and 5 mass $\%$ of the bochmite solution followed by homogenizing the mixture.

The binder viscosity was estimated by determining the flow curve; it means the empirical dependence of the stress $\tau$ on the shear rate $\gamma$, by means of the rotary rheometer RHEOTEST 2.

The measurement of the quartz wettability by a binder was based on recording the changes in the wetting angle value $\theta$ at the determined time intervals up to the stabilisation of the angle value by means of the prototype apparatus for the measurements in time [6].

The strength properties of moulding sands with fractions of modified binders were verified by testing the tensile strength $R_{m}^{u}$ after various hardening times under environmental conditions. The $R_{m}^{u}$ value after 24 h of hardening was assumed in the analysis.

\subsection{Obtained results and their discussion}

Flow curves of water glass at a temperature of $22{ }^{\circ} \mathrm{C}$ of not modified binder (curve 1) and modified by 1,3 and 5 mass \% of the bochmite solution (curves 2-4) - are shown in Figure 1.

As it results from the performed tests all binders are Newtonian fluids, satisfying equations (1)-(4):

- $\tau=0.1179 \gamma ; \mathrm{R}^{2}=0.9998 ;(1)$ - not modified water glass,

- $\tau=0.0935 \gamma ; \mathrm{R}^{2}=0.9999 ;(2)$ - water glass modified by 1 mass $\%$ of bochmite solution,

- $\tau=0.0782 \gamma ; \mathrm{R}^{2}=0.9996$; (3) - water glass modified by 3 mass $\%$ of bochmite solution,

- $\tau=0.0669 \gamma ; \mathrm{R}^{2}=0.9997$; (4) - water glass modified by 5 mass $\%$ of bochmite solution.

The binder viscosity - at $22{ }^{\circ} \mathrm{C}$ - equals app. $\eta=0.118$ [Pa $\left.\cdot \mathrm{s}\right]$ (for not modified binders), while for the binders modified by 1,3 and 5 mass $\%$ of $r-r$ bochmite the viscosity $\eta$ equals: $0.093[\mathrm{~Pa} \cdot \mathrm{s}] ; 0.078[\mathrm{~Pa} \cdot \mathrm{s}] ; 0.067[\mathrm{~Pa} \cdot \mathrm{s}]$, respectively. The performed tests indicate the influence of the modifier amount on viscous interactions. Settling of bochmite micro particles can also cause this influence. 


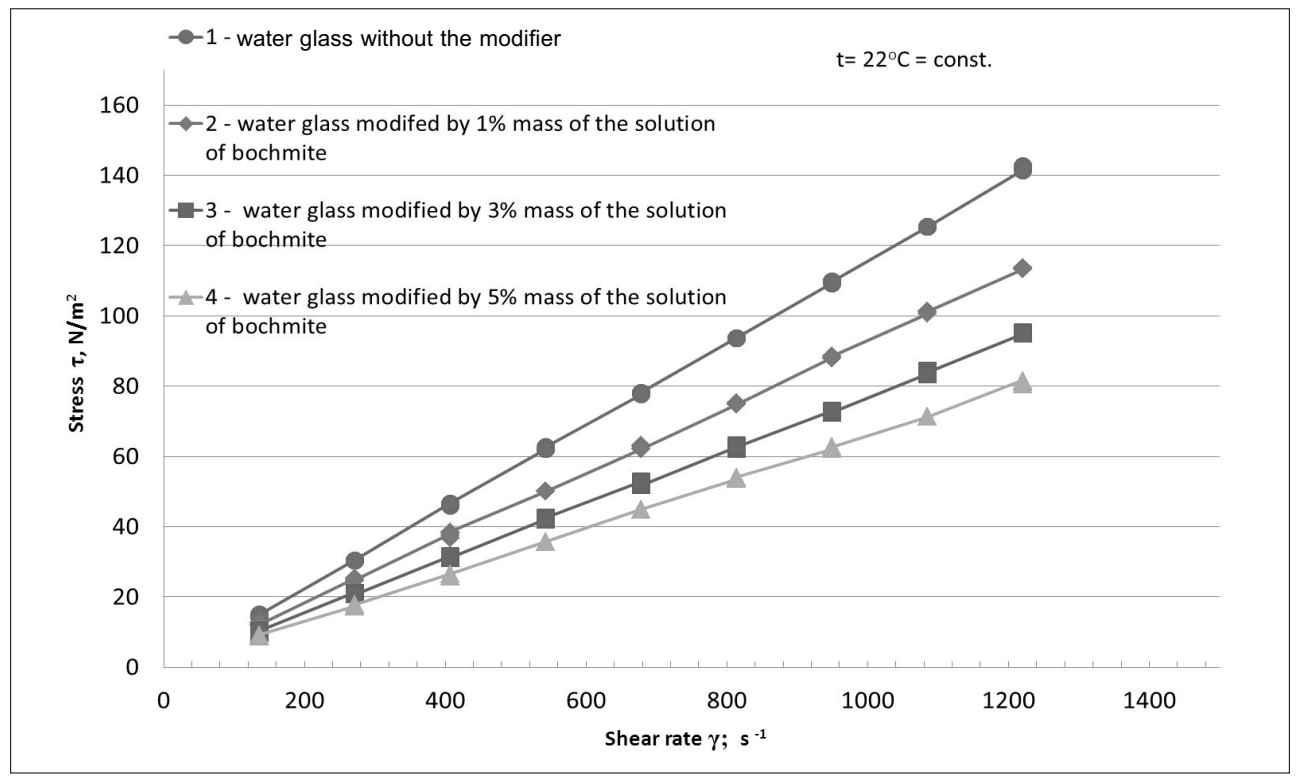

Fig. 1. Flow curves of water glass $R$ " 145 " modified by various additions of the bochmite solution

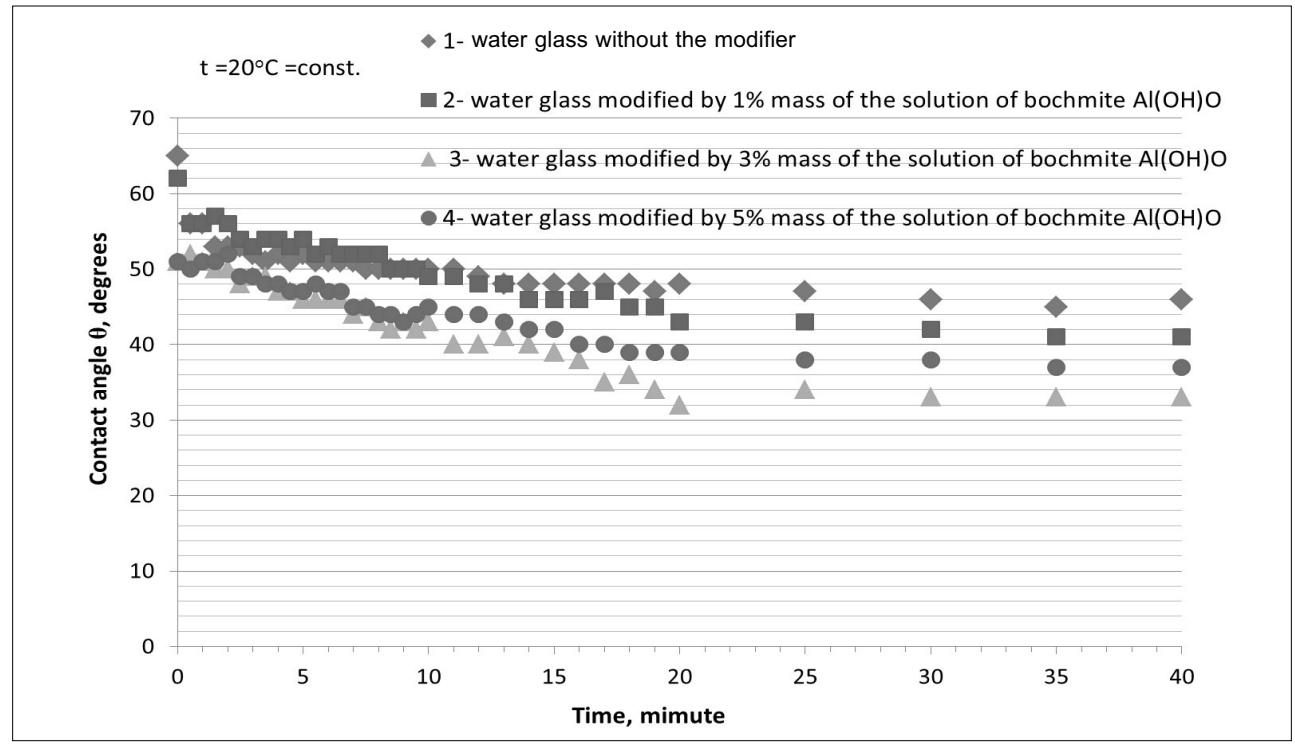

Fig. 2. Wetting angle $\theta$ changes with time, in the system quartz-water glass $R$ " 145 " modified by various additions of bochmite

The wetting angle $\theta$ changes (at $20{ }^{\circ} \mathrm{C}$ ) with time for the system: quartz - water glass (curve 1), quartz - water glass modified by the bochmite solution: 1 mass \% (curve 2), 3 mass \% (curve 3), 5 mass \% (curve 4) - respectively, are presented in Figure 2. 
The results presented in this figure indicate that the modifier decreases the initial $\theta_{0}$ as well as the equilibrium $\theta_{r}$ wetting angle value. This influence is especially seen for the binder modified by 3 mass $\%$. The initial wetting angles $\left(\theta_{0}\right)$ for the tested binders (curves from 1 to 4 ) are equal app. $66 \mathrm{deg}$. $61 \mathrm{deg}$. $50 \mathrm{deg} .51 \mathrm{deg}$. - respectively. They are decreasing to the equilibrium values of $\theta_{r}$ being respectively: $46 \mathrm{deg}$. (not modified binder), $41 \mathrm{deg}$. (modified by 1 mass \%), $34 \mathrm{deg}$. (modified by 3 mass \%) and $38 \mathrm{deg}$. (modified by 5 mass \%).

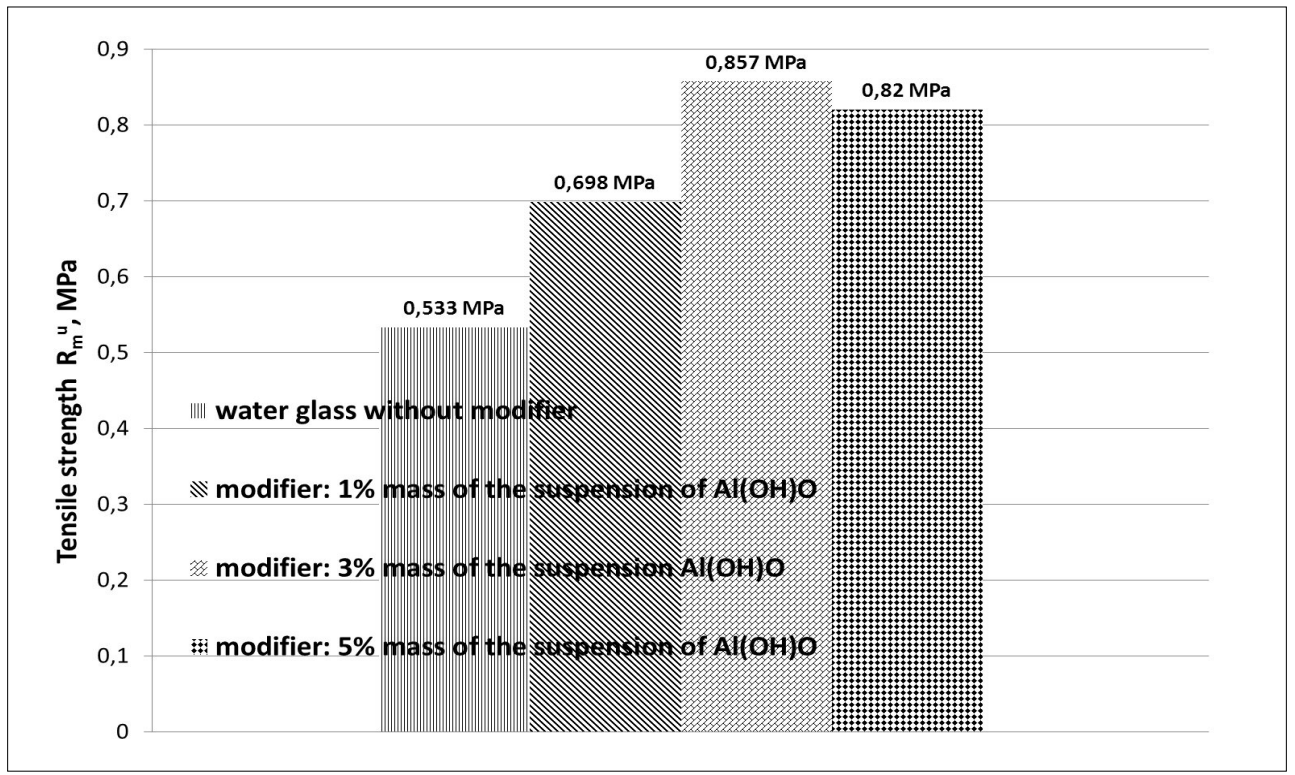

Fig. 3. Tensile strength $R_{m}^{u}$ of loose self-setting sands with water the glass. Composition of moulding sands (in parts by mass): 1) high-silica sand 'Szczakowa'-100, water glass '145'- 3, Flodur '3' - 10 mass \% in relation to water glass. 2) High-silica sand 'Szczakowa'-100, water glass '145'-3, modifier - 1, 3 and 5 mass \% of the bochmite solution AlOHO - respectively (in relation to a binder), Flodur ' 3 ' -10 mass $\%$ in relation to water glass. Hardening conditions: $t_{o t} \approx 22.5{ }^{\circ} \mathrm{C} ; W_{\text {wzg }} \approx 51 \%$; time $24 \mathrm{~h}$

Figure 3 illustrates the results of the tensile strength $R_{m}^{u}$ of loose self-setting sands with the water glass, not modified and modified by various additions (1, 3, and 5 mass $\%)$ of the bochmite solution $\mathrm{Al}(\mathrm{OH}) \mathrm{O}$ after $24 \mathrm{~h}$ of hardening.

The highest tensile strength $R_{m}^{u}$ being app. $0.86 \mathrm{MPa}$ obtains the moulding sand in which the binder is modified by 3 mass $\%$ of the bochmite solution. This value is app. $60 \%$ larger in comparison to the tensile strength $R_{m}^{u}$ of the initial sand and correlates with the measured wettability for the modified binder.

In addition, it is seen that even a small modifier addition ( 1 mass \%) provides a significant increase in the moulding sand strength $R_{m}^{u}$ by app. $31 \%$. 


\section{CONCLUSIONS}

- The performed investigations of viscosity and wettability of water glass modified by the water bochmite solution indicated the modifier influence on viscous interactions and quartz-binder interactions. This influence is especially seen at 3 mass $\%$ of the modifier addition.

- The tensile strength investigations of the loose self-setting sands with water glass, not modified and modified by various additions of the water bochmite solutions $\mathrm{Al}(\mathrm{OH}) \mathrm{O}$ indicate a significant modifier influence on the $R_{m}^{u}$ increase of moulding sands after $24 \mathrm{~h}$ of hardening under environmental conditions. This increase equals app. $60 \%$ for the sands with the binder modified by 3 mass $\%$ of the modifier.

\section{Acknowledgements}

The research was done within the 'Dean's Grant' 2011 No. 15.11.170.419

\section{REFERENCES}

[1] Zych J.: Rola zageszczenia w technologii formy opartej na masach ze szkłem wodnym lub spoiwem chemicznym, Przegląd Odlewnictwa, 21 (2005) 2, 88-97

[2] Zych $J .:$ Zachowanie się mas ze spoiwami chemicznymi w suchym powietrzu, Przegląd Odlewnictwa, 23 (2007) 9, 476-482

[3] Zych J.: Optymalizacja technologii formy opartej na masach ze szkłem wodnym utwardzanym estrami, Przegląd Odlewnictwa, 21 (2005) 12, 782-792

[4] Kuckui D.: Nowe kierunki rozwoju mas ze szkłem wodnym oraz elektrofizycznych metod ich regeneracji, Przegląd Odlewnictwa 6 (1990) 1, 95-200

[5] Ji-na W., Zi-tian F., Hua-feng W., Xuan-pu D., Nai-yu H.: An improved sodium silicate binder modified by ultra-fine powder materials, Ciuna Foundry, 4 (2007) 1, 26-30

[6] Hutera B., Smyksy K., Lewandowski J.L., Drożyński D.: Wybrane aspekty oznaczania zwilżalności osnowy przez materiały wiążące stosowane w masach formierskich, Archiwum Technologii i Automatyzacji, $23(2003) 1,63-70$

Received

December 2011 